\title{
Contemporary Social Problems in Nigeria and its Impact on National Development: Implication for Guidance and Counselling Services
}

\author{
Dr. I. N. George \\ University of Uyo, Uyo, Nigeria \\ Dr. D. E. Ukpong \\ University of Uyo, Uyo, Nigeria
}

\section{Doi:10.5901/jesr.2013.v3n2p167}

\begin{abstract}
This paper highlights the contemporary social problems, their direct and indirect impacts on the society and their possible solutions. Nevertheless, there is the common knowledge that we are living in an era of church denominationalism (church proliferation) yet crime rate and moral decadence increase daily in a geometrical progression thereby constituting a variance to the expected morality level. This is brought about mainly by modern science and technology amidst other predisposing sub variables such as peer group influence, examination malpractice, poverty, problem of heritance/succession etc as they affect our daily living and general well being. These social problems and their impact on the society are being examined in details and possible suggestions for curbing the menace for a sustained society are being proffered.
\end{abstract}

\section{Introduction}

It is believed that change is the only permanent factor in life and nothing is more permanent than change. These changes include growth in persons and thing which are commonly characterized by events that are either pleasant or unpleasant, desirable or undesirable and sometimes necessary or unnecessary.

In a modern society like Nigeria, many contemporary social problems have emerged which are against the norms, morals and ethics of our society and of course make life very uncomfortable. Such problems include our deviance behaviour toward the commandments of God e.g. as in our struggle for the control of available scarce resources wrongly and violently. This in turn creates problems in the society especially among the have and the have not.

The paper discusses these glaring social problems and their impact on the development of the society as well as the way forward. The contemporary problems under consideration include examination malpractices, drug abuse, juvenile delinquency, the negative impact of science and technology, poverty, examination malpractice, kidnapping and cultism among others. Solution about how these problems can be drastically reduced or managed are also discussed.

\section{Science and Technology:}

As mentioned earlier, science and technology though a blessing seems to be a curse to man and humanity over time. It is a two way traffic affair. Although it is the mother of inventions, a break through in modern business, facilitator of qualitative education and the controller or pivot of the modern day economy, expanding and covering larger frontiers of the universe in each new day, yet it is not without its own evil intentions.

The importance of science and technology include among others the invention of modern computer knowledge which has helped to solve today's complex statistical and related problems. The advantages also include the invention of aircrafts, cars, trains, ships etc to ease transportation problems, Hi-tech businesses, easy access to international and local business services and links, access to unlimited and global communication etc. 
Nevertheless, despite all these breakthrough that science and technology has recorded, it has been responsible for the alarming rate of crimes, injustice, killing and robbery, kidnapping and many other social disasters.

Among the negative impacts of science and technology are the Hitech business crimes e.g credit cards and internet robbery and theft, hooking on to false business link and contacts on the internet; cyber crimes which promote all forms of examination malpractice for example the use of phone for cheating in examination, phonographic shots and films which lure our youths to unhealthy and indiscriminate sexual activities, access to ungodly websites also known as (satan.com), juvenile robbery clips, unauthorized and destructive clips showing crimes, shooting and sexual lawlessness. Others are building of nuclear and sophisticated weapons of crime and war fare which are used by reckless youths and criminals e.g suicide bombers for crimes against humanity.

These and many more are readily available on the internets, home videos, crimes novels, journals and other publications etc. These are the negative impact of science and technology which threaten to destroy our society and also serve as spring boards for the proliferation of small and large scale crimes that result in total break down of law and order in the society.

\section{Juvenile Crimes:}

Juvenile crimes are those immoral behaviours exhibited by children below the ages of 18 (eighteen). Sometimes, they are overlooked or ignored by the parents, government and law enforcement agencies and are always rated as minor, meaning that they cannot or are not permitted by the law to stand trial by those who commit them. These juvenile crimes are classified into three types namely: (i) juvenile delinquency (ii) gang delinquency and (iii) Neurotic delinquency i.e a type of symbolic stealing by isolated children.

There are many factors that lead to delinquency in children; these are (i) lack of adequate parental care (ii) negative peer group influence (iii) poverty resulting in under-feeding and inadequate provision of necessary basic of needs, (iv) lack of proper guidance and counselling services which usually help individuals to overcome obstacles (Anagbogu, 1988).

\section{Suggested Remedies}

To effectively curb the problems of juvenile delinquency, parents and care givers are the primary salvaging agents to give adequate care and corrections on time. This is because the home is the first point of socialization of the child and usually creates long-lasting corrective measures to curtail juvenile delinquency. This could be achieved by controlling what are being produced in our home videos, recreational centers and cinema houses. Also, the training of a child should not be left in the hands of the parents alone. The community, church and non-governmental organizations should be involved in correcting children since they do not belong to their parents alone and above all, their behaviour will impact positively or negatively on every member of the society.

\section{Hi-Tech Robbery Activities}

The upsurge of new dimensional and hi-tech crimes such as kidnapping, bank and armed robbery activities in many parts of Nigeria has called for concern of the government and well-meaning Nigerians. In most cases, innocent lives are sorrowfully terminated in the process; for example the robbery attack on the Akwa Ibom State House of Assembly on Friday August 10, 2011 and that of Guaranty Trust Bank along Abak Road on Tuesday, August 23, 2011, where many lives were destroyed among many others casualties. Internet scam, credit card robbery, internet pornography and other related offences prevalent in our society among the youths and adults today are traceable to lack of gainful or meaningful employment and other factors like peer groups influence and parental negligence. Majority of those involved in these crimes are actually trained graduates in such related areas who are supposed to use such knowledge productively in gainful employment and proper guidance but they turn around and use such knowledge negatively to pull down the society. Also the recent bombings by suicide bombers and AIEQ'AEDA groups on June 16, 2011 at the Police Force Headquarters in Abuja, Nigeria) where (15) fifteen people were killed including the sinking down of the United Nations House on August 26, 2011 where many people were killed and others injured is also a new dimension of hi-tech anti-social activities by a religious sect known and referred to as Bokko Haram. 


\section{Suggested Remedies}

These could be checked through the provision of gainful employment, proper and effective counselling services, proper upbringing of children with sound moral instructions. There is also the crucial need for government to set up regulatory laws to strictly monitor the activities of the internet service providers and users by enacting relevant sanctions for those who break the moral codes of the regulatory framework.

\section{Poverty}

Poverty is one of the contemporary social problems affecting Nigeria as a third world country. It is a state of complete lack of minimal means of livelihood. Judging by the American standard, about eighty five percent (85\%) of Nigerians are poor. This gives birth to incidence of high involvement of her citizens in criminal activities such as corruption, bribery and all types of immoral conducts. Poverty as a concept may not be new in the world's history book but the consciousness of it, is relatively new as a result of the sudden economic melt down, devaluation of naira, civil unrest, ethnic and tribal crisis etc (Ibia, 1999). The poor lacks the means to satisfy the basic needs of life. They do not have personal assets necessary to produce income and wealth (Famoyin, 2007).

An average Nigerian family may be unable to afford (3) three square meals a day. In many parts of the world, poor people are regarded as those people who cannot for one reason or the other have economically productive role by economic standards to provide adequate income for themselves. Poor people are not only deprived of most material comfort of life but also cannot attain their maximum emotional and social development (Thompson, 2008). It is not difficult to differentiate between a poor person from his rich counterpart using the yardstick stated above.

First there is a psychological standard of poverty which measures a poor person's income as falling behind his basic need capacity. Secondly, a poor person can always be identified by lack of emergency medical care and the kind of shelter and clothing that protect his life (Hanson, 2010).

\section{Causes of Poverty}

The major causes of poverty include lack of employment and inadequate care which invariably result in high level of dependent population.

Overpopulation: This affects the meagre salary of the family. The dependent groups include the aged, females and family heads, the total number of children in the family including other dependent relatives that are non-marginal workers in the family.

The aged people are those who are seventy years and above. Some of them are retired workers whose pension and gratuity are not regularly paid, but they have special needs. In Europe and America, the aged are cared for in special centres called Old Peoples Homes, and they are entitled to a certain welfare scheme called "Old Age Benefits" and as such they are no burden to their families unlike what is obtain in Nigeria and other third world countries where old people are mandatorily cared for by their relatives (Des Wilson, Ikorok Maria, 2010).

\section{Kidnapping:}

Kidnapping is that act of forcefully taking someone hostage or custody usually through the use of arms or weapons for purpose of ransom. Recently, this criminal act has become wide spread and very frequent as a result of the monetary inducement of the process. Most often, the victims so captured are usually kept in an unknown place and the victims' relatives are compelled to pay certain amount as ransom to secure the victim's release and failure to comply within the specified time, the victim may be killed (Lambora, 2009). Though kidnapping is both legally and morally wrong yet thousands of youths find it as a lucrative business especially the unemployed youths. This can be checked by provision of employment opportunities though some people are also kidnapped for other reasons. 


\section{Cultism:}

A cult may be defined as a group of people who follow a system of worship, especially one that is different from the usual and established forms of religion in a particular society. It can also be a particular, often temporarily fashionable system of (religious) worship or belief (Ukpong, 2003). Objectively, members of such group have an exclusive or distinct ideology and ritual practices centred on sacred symbols. The origin of cultism in Nigerian schools can be traced back to 1968 at the University of Nigeria now University of Ibadan where the first secret cult was established by Wole Soyinka (now Professor) and his friends. The name of the cult group was pirates confraternity (sea dogs) with positive agenda towards promoting the African culture on campuses and to create positive changes within the campus environment.

However, the aims and objectives of such groups have for over a decade or three now changed from constructive to destructive motives thereby killing the dreams and sabottashing the efforts of the primary frontiers of such groups. Sadly enough, both graduates and under graduate youths are enormously involved on a daily basis. Cultists seek out strong intelligent, idealist people. Their aim is to make their recruits vulnerable using mind control. The occultic group or cultic activities are criminal in nature and also morally wrong and has tremendous negative effects on the society. Their activities include killing, robbery, raping, drug abuse, forgery, examination malpractice, impersonification etc. Cultism is a character related social problem which youth empowerment or creation of sustainable job opportunities may not be able to eradicate rather rehabilitation and proper counselling may help.

\section{Large Family Size}

About half of all the families with six or more children are generally poor as they do not earn adequate money to cater for their needs. This is why children from large families are greatly malnourished because of poverty. Unfortunately in Nigeria, the people who have large family size are most affected. Since Nigerian government lack sustainable welfare services, the poor tends to be poorer continually while the rich are richer, great distinction between the haves and the have not.

According to Ukpong (2003), the Federal Government National Population Policy (1998) states that "it is possible for us as a nation to control our fertility and reduce our excessive rate of population growth in order to minimize or reduce their adverse effects on our lives.

\section{Number of Marginal Workers in the Family}

All wage earners in Nigeria are under the group of marginal workers. It is difficult to have two to five marginal workers in all Nigerian families. Most of the people are attending schools at different levels from nurseries to university; some are very old grannies being catered for by their relatives who are the few marginal workers. These few have less opportunity to save as they are supporting the aged people, and are also responsible for themselves and their children's education, (Fumoyin, 2007).

Today, salaries of marginal workers in Nigeria never take them two weeks in the new month. As a result, the workers become objects of ridicule in the society as they borrow and buy items on credit.

Suggested Remedy: The importance of creating sustainable job opportunities cannot be overemphasized. This is because more than half to those confined to poverty level are graduates without jobs; even those without basic qualifications can be trained through skill acquisition programmes by the government. Beside, moral instructions by parents, religious bodies and care givers are also relevant.

\section{Examination Malpractice}

In recent times, malpractice in examination has gone hi-tech e.g internet aid, and the use of GSM phones etc. Examination malpractice exists in various names and forms, some of which are very shameful, others apparently glorious but evil. Amakiri (1996) in Ukpong (2003) also Afigbo (1996) in Ukpong (2003) describe it as a demon with a thousand faces and they come under various code names such as "bullet", "missiles", "walkie talkie", 
"super print", "computer", "ekpo", " brain support", etc. The increasing rate of examination malpractice could be attributed to the following factors.

(i) Poor Teaching: This could be caused by lack of proper teaching and use of poor teaching methods. Students who are not well taught are not well vessed with the knowledge of the lesson, and are absolutely ignorant hence cheating is the only alternative to passing examination since failure itself carries certain degree of stigmatization. This suggests the need to employ only competent teachers.

(ii) Ineffective Preparation by Students: Deviants regard learning and studying as punishment and so do not prepare effectively for examinations. They resort to all forms of malpractice such as copying, storing of information in GSM phones, or going with any form of prepared materials (micro chips) into examination hall just to pass examination.

(iii) Ill-Equipped Library Facilities: A library is a reservoir of knowledge and a research unit. Lack of wellequipped library poses a serious setback to research and learning. In such situations, examinations malpractice is inevitable. It is like a central laboratory of the whole schools (Edem, 2010). The library facilities include textbooks, magazines, newspapers, pamphlets, films, slides, tape recorders, programmed instructional materials and prints.

\section{Dubious Admission Policy}

The dubious nature of admission policies adopted by some schools make "academic misfits" to be admitted and given placement in schools. Due to the fact that admissions these days are through God-fatherism and bribery in most schools and not by genuine academic achievement, the students so admitted have no basic qualifications. It would be impossible for them to do well hence, they finally resort to examination malpractice.

Suggested Remedy: Admission should be based on merit.

\section{Government Overemphasis on Certificate}

In Nigeria, employments are based solely on certificates and not on skills acquisition. One is not rewarded without a certificate to back up; no matter how intelligent one may be on the job. As a result of this overemphasis on certificate acquisition by government, students by all means involve themselves in examination malpractice in order to get the certificate so as to enable them secure jobs.

Suggested Remedy: Sound and qualified teachers should be employed in our schools. Also, better teaching aids and materials should be provided by the government. Students should properly counselled to take their studies seriously. Government should not place too much emphasis on paper qualifications only but should rather learn to reward talents; this can drastically reduce examination malpractices. Government and other stakeholders in education should also consider building and equipping libraries as well as employing competent hands into the educational sector.

\section{Drug Abuse}

A drug is any substance which when taken into the body modifies or alters the normal functions. Drug abuse is therefore the unspecified use of drugs against the prescribed medical purposes. It is also self administration of drugs. Commonly abused drugs are referred to as "psychoactive drugs". That is, those drugs which exert their major effects on the brain and the central nervous system producing sedation, stimulation or changed mood.

Names of commonly abused substances and drugs include tobacco, alcohol, cocaine, heroine, Indian hemp, cannabis, opium, amphestamine, kolanuts, coffee, asprin, codeine, panadol, paracetamol etc. Drug abuse leads to drug addiction and drug addiction is referred to as a state of period or chronic intoxication produced by the repeated consumption of unprescribed or prescribed drugs. Drug abuse brings about addiction, habituation or dependence. However, not all abused drugs or substances are capable of producing addiction and habituation. Drug dependence is made up of emotional and physical dependence. Emotional dependence is a condition in which the drug or substance promotes a feeling of satisfaction and a drive to repeat its consumption in order to induce pleasure (Anwana, 1989). 
Physical dependence is characterized by compulsion to take the drug or substance on a continuous basis in order to experience its mental effects an avoid the discomfort of its absence/as tolerance sets in the drug abuser realizes that, he needs progressively increasing doses of the drug or substance to remain "normal" and to avoid the withdrawal syndrome characterized by a combination of anxiety, insomnia, tremor, headache, restlessness, increased perspiration, vomiting, diarrhea, hallucination and even death.

Suggested Remedy: The government under the platform of (NAFDAC) - National Agency for Food and Drug Administration and Control should put in place relevant and effective machineries to regulate the distribution of drugs in hospitals, dispensaries and pharmacies especially "off shelf drugs" (i.e. sending out of monitoring teams to monitor the dispension of drugs at designated centres). They should ensure that fake and expired drugs are not sold to consumers but destroyed and put more effective bands on the importation of drugs which distort the normal functions of the body (hard drugs). On the other hand, the public should be fully sensitized on the dangers of self medication.

\section{Films and Movies}

As earlier mentioned, the films and movie makers have been in the forefront of the entertainment industries exposing crimes as well as portraying ways of combating them through their film show. However, this has not produced only the desired positive results but has also been responsible for the hi-tech nature of crimes especially youth oriented crimes.

Common among this crime enhanced movies are numerous strategies of malpractice in examinations. These include:

- Hi-tech business crimes (credit card and internet theft, hooking of false business links etc which is well taught in the movie called "Boys Cot" of which many youths would not have originally known the rudiments or basis of such crimes.

- The issue of pornographic clips, films and shots openly sold in the markets and movie outlets are highly immoral although it may not be illegal. Decades before now, the entire process of sexual relations was highly restricted and private but regrettable enough, socialization has brought what is known as "Adult films" where sexual practice is taught in details and is quite at the disposal of the young and old. In such circumstances, the movie industry is at the forefront of promoting immorality and this invariably inspire youths to early sexual activities and unprotected sex which mostly results in sexual transmitted infections and unwanted pregnancies etc.

Suggested Remedy: In order to combat the outrageous contributions of the movie makers; government should stand on its feet through the Films Commission and Censorship Board to band and prosecute those who are involved in the production and shooting of the so-called "Adults Films" and other immoral movies in order to checkmate the propagation of new dimensions of violent crimes as well as the invention of new ones.

\section{Conclusion}

This paper discussed some of the contemporary social problems now prevalent in the Nigerian society. They include poverty, examination malpractice, juvenile delinquency, drug abuse, kidnapping, cultism, crime proned films and movies among others. The effect of these problems on the society has been highlighted to include high dependency rate, low per capita income, unwanted pregnancy, general disorder, moral decadence among others. Appropriate suggestions to combat these problems have also been offered. Prominent among these are: Creation of sustainable job opportunities and provision of basic skill acquisition programmes for graduates, for both low and middle level man power. Secondly, parents and care givers have enormous tasks to train the children in the way of the Lord such that when they grow up they will not depart from it. Finally, the church and community should teach sound and good moral doctrines to all children because these children are not only for their parents but also for everybody and the entire society.

\section{Recommendations}

The following recommendations are made from this paper: 
1. Government should create jobs opportunities for the teaming population of unemployed youths.

2. Education should be free in the real sense of it and admission into schools should be on merit.

3. As Africans we should go back to the roots and embrace our traditional values which the community used to punish an offender of laws and customs and not try to embrace the culture of excessive child pampering to the extent of ignoring discipline (it is my own child and not your own).

4. Parents should not spare the rod and spoil the child, rather they should teach the child all that is needed to be Godly and a good citizen as well.

5. Parents should learn to be satisfied with the potentials of their children and not for them to desire what their children cannot attain to a point of abating examination malpractice in order to achieve their fantasies.

6. Government should reward talents and not place so much emphasis on paper certificate or qualifications.

7. Admission and employment should be done on merit and not through godfatherism.

8. Defaulters and law breakers should be punished severely to serve as a deterrent to others and no favouritism.

\section{References}

Anagbogu, M. A. (1988). Foundation of guidance counselling. New York: John Willey and Sons.

Anwana, V. I. (1989). Psychology: Aspects of human development. Enugu: Academic Press Development.

Famoyin, V. O. (2007). Foundation of economy of west Africa. Ilesha: Illesanmi Press.

Hanson, B. T. (2010). Leadership and social development of people. Journal of Elementary School, 1(2).

Holy Bible - Revised Standard Version.

Ibia, E. I. (1999). Sociological foundation of Nigerian education. Calabar: Cats Publishers.

Lambora, V. E. (2009). Leadership behaviour of militant youths in the Niger Delta region. Educational Development Journal, 1(2).

Thompson, E. F. (2008). Basic income and poverty alleviation in rural areas of west Africa. Ibadan: Evans Publishers Ltd. Ukpong, D. E. (2003). Essentials of sociology of education. Uyo: Afahaide and Brothers \& Co. 
